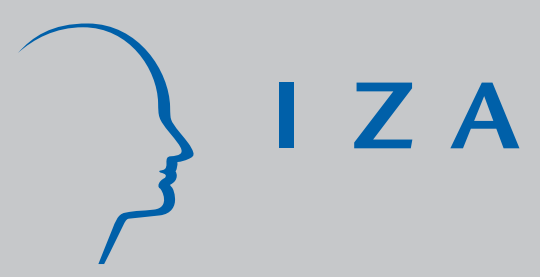

IZA DP No. 2924

Interprovincial Migration in China:

The Effects of Investment and Migrant Networks

\author{
Shuming Bao \\ Örn B. Bodvarsson \\ J ack W. Hou \\ Yaohui Zhao \\ J uly 2007
}




\title{
Interprovincial Migration in China: The Effects of Investment and Migrant Networks
}

\author{
Shuming Bao \\ University of Michigan \\ Örn B. Bodvarsson \\ St. Cloud State University \\ and IZA \\ Jack W. Hou \\ California State University, Long Beach \\ Yaohui Zhao \\ Beijing University
}

Discussion Paper No. 2924
July 2007

IZA

P.O. Box 7240

53072 Bonn

Germany

Phone: +49-228-3894-0

Fax: +49-228-3894-180

E-mail: iza@iza.org

\begin{abstract}
Any opinions expressed here are those of the author(s) and not those of the institute. Research disseminated by IZA may include views on policy, but the institute itself takes no institutional policy positions.

The Institute for the Study of Labor (IZA) in Bonn is a local and virtual international research center and a place of communication between science, politics and business. IZA is an independent nonprofit company supported by Deutsche Post World Net. The center is associated with the University of Bonn and offers a stimulating research environment through its research networks, research support, and visitors and doctoral programs. IZA engages in (i) original and internationally competitive research in all fields of labor economics, (ii) development of policy concepts, and (iii) dissemination of research results and concepts to the interested public.
\end{abstract}

IZA Discussion Papers often represent preliminary work and are circulated to encourage discussion. Citation of such a paper should account for its provisional character. A revised version may be available directly from the author. 


\section{ABSTRACT \\ Interprovincial Migration in China: The Effects of Investment and Migrant Networks}

Since the 1980s, China's government has eased restrictions on internal migration. This easing, along with rapid growth of the Chinese economy and substantial increases in foreign and domestic investments, has greatly stimulated internal migration. Earlier studies have established that migration patterns were responsive to spatial differences in labor markets in China, especially during the 1990s. However, other important economic and socio-political determinants of interprovincial migration flows have not been considered. These include the size of the migrant community in the destination, foreign direct and domestic fixed asset investments, industry and ethnic mixes and geographic biases in migration patterns. We estimate a modified gravity model of interprovincial migration in China that includes as explanatory variables: migrant networks in the destination province, provincial economic conditions, provincial human capital endowments, domestic and foreign investments made in the province, industry and ethnic mixes in the province, provincial amenities and regional controls, using province-level data obtained from the National Census and China Statistical Press for the 1980s and 1990s. We find strong evidence that migration rates rise with the size of the destination province's migrant community. Foreign and domestic investments influence migration patterns, but sometimes in unexpected ways. We find that as economic reforms in China deepened in the 1990s, the structure of internal migration did not change as much as earlier studies have suggested. Consequently, our results raise new questions about the World's largest-scale test case of internal migration and strongly suggest a need for further research.

JEL Classification: J61

Keywords: internal migration, investment, migrant networks

Corresponding author:

Örn B. Bodvarsson

Department of Economics

St. Cloud State University

720 Fourth Avenue South

St. Cloud, MN 56301

USA

E-mail: obbodvarsson@stcloudstate.edu

\footnotetext{
* We thank Gewei Wang and Robert Girtz for assistance in the assembly of our data set and bear full responsibility for any errors.
} 


\title{
I. INTRODUCTION
}

\section{For researchers studying internal migration in transition economies, China is a}

\author{
tremendously valuable natural experiment. Since the 1980 s, there has been a gradual \\ easing of restrictions on internal migration in China. ${ }^{1}$ During the same period, several
} broad comprehensive market reforms ${ }^{2}$, globalization and large infusions of foreign direct investment all created considerable prosperity in China but also contributed to significant interregional income inequality. Consequently, China experienced a surge in internal migration between the 1980s and 1990s. Based on the 1\% population sample survey of

\footnotetext{
${ }^{1}$ For those not familiar with the migration-related policy changes in China, between 1949 and 1978 migration within China was very strictly controlled by the government's hukou system, a household registration system that was designed to directly regulate population redistribution, as well as to provide the government with a mechanism for gathering population statistics and to identity personal status. Under the hukou system, households had to register with the government, the government assigned persons jobs and rationed living necessities in urban areas. If a person wanted to move, approval had to be obtained from his/her local government. Consequently, intra- and interprovincial migration were rare, except for situations involving "planned" migration from the Eastern parts of the country to the much less-populated Western areas during the Cultural Revolution period of the 1960s and 1970s. Since 1978, when the government initiated the Comprehensive Economic Reform (CER) program, the hukou system has been incrementally dismantled. The first step towards dismantling came with the introduction of identity cards in the late 1980s, which allowed persons to travel around China without showing an official "permission" letter from his/her local government. The next step was the abolition of grain rationing coupons in the early 1990s; these coupons were the means by which people obtained food rations and they could only be used in the place of residence. With the abolition of the coupons, individuals were free to obtain food where they wished. A third step occurred in 2001, when residency in small towns and townships was open to all rural workers who were legally employed and had a place to live. At roughly the same time, medium-sized cities and some provincial capitals eliminated ceilings on the number of rural workers who could apply for permanent residence status. Some very large cities such as Shanghai and Beijing concurrently eased restrictions on the in-migration of rural workers.

${ }^{2}$ The first reform was the decollectivization of agriculture (also known as the inception of the household responsibility system) in rural areas. The most important aspect of this reform is that it freed workers to choose how they wanted to allocate their labor supplies. This encouraged many workers to leave the agricultural sector and seek employment in other sectors, most notably enterprises in urban areas. The second consisted of a set of market-oriented reforms in the urban areas during the late 1980s. The government, in an effort to attract foreign direct investment, created favorable provisions, e.g. tax concessions and attractive terms for leasing land, to many coastal cities so they could establish economic development areas and high technology development zones. In the 1990s, the government gave special tax and regulatory treatment to certain areas (called "special economic zones"), which generated large amounts of FDI in those areas. These economic reforms had the effect of creating large real income differentials between the Eastern provinces and the rest of China, encouraging Eastward migration.
} 
1987, it is estimated that over 30 million Chinese relocated either within or between provinces during 1982-87. Using data from the 2000 Chinese Census, researchers have estimated that intra- and interprovincial migration during 1995-2000 totaled over 144 million persons, or about $12 \%$ of average provincial population during that period. Much of the surge in migration involved rural residents moving to urban areas, particularly the metropolitan coastal cities and Beijing.

Prior to 1987, research on internal migration in China was severely hampered because national level data on internal migration was generally non-existent. The first national survey that included questions about migration was the $19871 \%$ population survey and 1990 was the first year in which the government collected data on migration in the population census. The 1990 census asked questions about both inter- and intraprovincial migration for the period 1985-90 and the 2000 census included questions about migration during 1995-2000. There have also been a number of household surveys in very specific areas of the country, which have included questions about migration.

As a result of this relatively new data on migration patterns, a small and mostly empirical literature focusing on the determinants of internal migration in China has begun to emerge. This literature consists of a handful of studies utilizing micro-data obtained from special household surveys (see, for example, Liang (2001), Liang and White (1996,1997), Zhao (1997,1999a, 1999b, 2002, 2003), Liang, Chen and Gu (2002)) and a few studies utilizing province-level aggregate data provided by the central government (see, for example, Lin, Wang and Zhao (2004), Poncet (2006) and Bao, Hou and Shi (2006)). The primary objective of these studies has been to ascertain to what extent an 
individual's propensity to migrate (or the strength of aggregate migration flows) are driven by regional differences in labor markets.

Among the studies that have utilized province-level aggregate data on migration flows, the general finding has been that flows were responsive to regional differences in income and unemployment rates during the 1980s and 1990s, controlling for other factors, but the responsiveness of migration to changes in those rates was generally greater during the 1990s. ${ }^{3}$ These results suggest that as Chinese economic reforms deepened in the 1990s, the structure of internal migration changed considerably. These studies also found that migration flows are inversely related and very sensitive to distance between origin and destination (Lin, Wang and Zhao (2004), Poncet (2006), Bao, Hou and Shi (2006)) and domestic trade barriers (Poncet (2006)), positively related to the destination population's level of educational attainment ${ }^{4}$ (Lin, Wang and Zhao (2004)) and responsive to regional differences in climate (Lin, Wang and Zhao (2004)), the agricultural industry's share of provincial employment (Bao, Hou and Shi (2006)) and the share of the destination province's population consisting of persons belonging to minority groups (Bao, Hou and Shi (2006)).

In this study, we contribute to ongoing research on the determinants of interprovincial migration flows in China by examining several fundamental determinants not examined

\footnotetext{
${ }^{3}$ For example, Lin, Wang and Zhao (2004), using 1990 and 2000 Census data on interprovincial migrant flows, found that after controlling for distance, relative educational attainment, relative unemployment rates, the relative degree of urbanization and climatic differences, migration did not respond to income differences during 1985-90, but was relatively sensitive to those differences during 1995-2000. Poncet (2006), utilizing both Chinese Census data from 1990 and 2000 and 1995 National Population Survey data, found that migration was responsive to regional income differences during the 1980s and 1990s, but the responsiveness was greater in the later period. Both studies attribute the greater sensitivity of interprovincial migration to spatial differences in income during the later period to the significant reduction in migration barriers that occurred during that period. Both these studies measured income as mean per capita income in each province, obtained from the National Bureau of Statistics. In contrast, however, Bao, Hou and Shi (2006), using data on per capita GDP to proxy provincial income per capita, found that during the 1990s there was actually no relationship between income and interprovincial migration flows.

${ }^{4}$ Only for the 1990s, however.
} 
in earlier studies. The first is the size of the migrant community in the destination. Many studies on both internal and international migration have confirmed that current flows of migrants from place $i$ to place $j$ are often strongly influenced by the number of persons residing in $\mathrm{j}$ who previously migrated from $\mathrm{i}$. These are often called "kinship" or "network" effects on migration; the presence of friends, family and other contacts already at the destination tends to lower the psychic and information costs generated by migration. Zhao (2003) examined the influence of migrant networks on Chinese internal migration using micro-level household survey data from a very specific location in rural China and found that experienced migrants have a positive and significant effect on subsequent migration, although return migrants apparently have no effect. One of the goals of our study is to ascertain whether Zhao's results are generalizable to all of China through a study utilizing aggregate data on province-to-province migration flows.

A second factor we contend will influence migration is investment spending in the province, specifically domestic fixed asset investment (which consists primarily of residential and commercial construction spending) and foreign direct investment (FDI). Between the 1980s and 1990s, there have been substantial increases in both types of investment spending in most of the provinces. According to the China Statistical Press, mean annual per capita FDI in each province soared from US\$3.14 during 1985-90 to US\$44.62 during 1995-2000. Much of this increase went to specific areas in the country designated by the government to receive special treatment with respect to economic development. According to the same source, mean annual fixed asset investment per capita in each province rose from 89 Yuan during 1985-90 to 247 Yuan during 19952000. We hypothesize that higher investment spending in a province will induce 
"demand-pull" migration; greater spending on infrastructure, for example, will increase the demand for labor, including migrant labor. Liang and White (1997) tested for the effects of province-level foreign investment on the likelihood of an individual migrating from the province using data taken from a 10\% random sample of the China 2/1,000 Fertility and Birth Control Survey, and found no evidence of such effects. We contend that any effects of FDI or domestic fixed asset investment spending on migration decisions are much more likely to be observed in aggregate data, as opposed to microdata sets obtained from household surveys in very small parts of the country. One goal of this study is to examine the relationship between aggregate migration flows and both types of investment.

We also consider the possible influences of industry and ethnic mixes in the province and regional biases in migration patterns. We hypothesize that the extent of emigration will be influenced by the dominance of manufacturing in the destination province relative to the origin province, as well as the dominance of the minority population (which was also examined by Bao, Hou and Shi (2006)). Furthermore, we control for region of destination in order to ascertain whether, all other things equal, there were greater tendencies for Westward or Eastward migration.

The remainder of this paper is organized as follows. In the next section, we present a version of a modified gravity regression model of interprovincial migration flows, followed by a discussion of our data set and then empirical results obtained from OLS estimation. The final section discusses implications for future research. 


\section{THE DETERMINANTS OF INTERPROVINCIAL MIGRATION ; THEORY and EMPIRICAL SPECIFICATION}

We estimate a version of the traditional modified gravity model of internal migration, which is applied here to the case of interprovincial migration in a developing country experiencing substantial market reforms. ${ }^{5}$ Unique to this version is the inclusion of provincial investment and migrant network controls, as well as other controls for a province's economic, political and social characteristics. The dependent variable is the $\log$ of the gross interprovincial emigration rate in period $t\left(\log \left(\mathrm{M}_{\mathrm{ij} t}\right)\right)$, calculated as the volume of out-migration from province $\mathrm{i}$ to province $\mathrm{j}$ during the period divided by total interprovincial migration from province i during that period. The equation to be estimated is

(1) $\log \mathrm{M}_{\mathrm{ijt}}=\alpha_{0}+\alpha_{1} \log \mathrm{D}_{\mathrm{ij}}+\alpha_{2} \operatorname{logNETWORK} \mathrm{ijt}+\alpha_{3} \log \mathrm{FDI}_{(\mathrm{i})(\mathrm{t}-\mathrm{k})}+\alpha_{4} \log \mathrm{FDI}_{(\mathrm{j})(\mathrm{t}-\mathrm{k})}+$ $\alpha_{5} \log I N V_{(i)(t-k)}+\alpha_{6} \log I N V_{(j)(t-k)}+\alpha_{7}\left(\log I N V_{(i)(t-k)}\right)(\operatorname{logFDI}(i)(t-k))+$ $\alpha_{8}\left(\log I N V_{(j)(t-k)}\right)\left(\log F_{(j)(t-k)}\right)+\alpha_{9} \log Y_{i t}+\alpha_{10} \log Y_{j t}+\alpha_{11} \log E_{i t}+\alpha_{12} \log E_{j t}+\alpha_{13} \log U_{i t}+$ $\alpha_{14} \log \mathrm{U}_{\mathrm{jt}}+\alpha_{15} \log \mathrm{MANU} \mathrm{it}_{\mathrm{it}}+\alpha_{16} \log \mathrm{MANU} \mathrm{jt}_{\mathrm{jt}}+\alpha_{17} \log \mathrm{MIN}_{\mathrm{it}}+\alpha_{18} \log \mathrm{MIN}_{\mathrm{jt}}+\alpha_{19} \log \mathrm{T}_{\mathrm{it}}+$ $\alpha_{20} \log \mathrm{T}_{\mathrm{jt}}+\alpha_{21}$ NORTHWEST $_{\mathrm{j}}+\alpha_{22}$ SOUTHWEST $_{\mathrm{j}}+\alpha_{23}$ EAST $_{\mathrm{j}}+\alpha_{24}$ PERIOD $_{\mathrm{t}}+\varepsilon_{\mathrm{ijt}}$ where:

$\mathrm{D}_{\mathrm{ij}}=$ railway distance (in kilometers) between the capital city of province $\mathrm{i}$ and that of province $\mathrm{j}$;

NETWORK $_{i j}=$ the size of the migrant community already residing in $\mathrm{j}$ that hails from $\mathrm{i}$, measured as the ratio of the stock of migrant residents to population;

$\mathrm{FDI}_{(\mathrm{i})(\mathrm{t}-\mathrm{k})}, \mathrm{FDI}_{(\mathrm{j})(\mathrm{t}-\mathrm{k})}=$ real foreign direct investment per capita spent in provinces $\mathrm{i}$ and $\mathrm{j}$, respectively, lagged k periods;

$\mathrm{INV}_{(\mathrm{i})(\mathrm{t}-\mathrm{k})}, \mathrm{INV}_{(\mathrm{j})(\mathrm{t}-\mathrm{k})}=$ real domestic fixed asset investment per capita spent in provinces $\mathrm{i}$ and $\mathrm{j}$, respectively, lagged $\mathrm{k}$ periods;

\footnotetext{
${ }^{5}$ See Greenwood (1997, pp. 663)
} 
$\mathrm{Y}_{\mathrm{i}}, \mathrm{Y}_{\mathrm{j}}=$ real per capita income in provinces $\mathrm{i}$ and $\mathrm{j}$, respectively;

$E_{i}, E_{j}=$ mean number of years of schooling completed by residents of province $i$ and $j$, respectively, 25 years of age and above at the beginning of the period;

$\mathrm{U}_{\mathrm{i}}, \mathrm{U}_{\mathrm{j}}=$ unemployment rates during the week preceding the implementation of the census in province $\mathrm{i}$ and $\mathrm{j}$, respectively;

$\mathrm{MANU}_{\mathrm{i}}, \mathrm{MANU}_{\mathrm{j}}=$ proportion of provincial GDP comprising the manufacturing sector in province $\mathrm{i}$ and $\mathrm{j}$, respectively;

$\mathrm{MIN}_{\mathrm{i}}, \mathrm{MIN}_{\mathrm{j}}=$ proportion of population comprising minorities in province $\mathrm{i}$ and $\mathrm{j}$, respectively;

$\mathrm{T}_{\mathrm{i}}, \mathrm{T}_{\mathrm{j}}=$ mean yearly temperature in the capital city of province $\mathrm{i}$ and $\mathrm{j}$, respectively;

NORTHWEST $_{\mathrm{j}}=$ dummy variable equaling one if the destination province is one of the Northwestern provinces; ${ }^{6}$

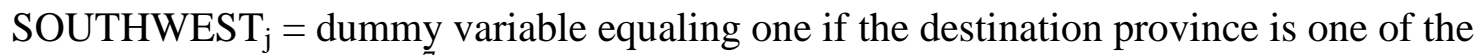
Southwestern provinces; ${ }^{7}$

$\operatorname{EAST}_{\mathrm{j}}=$ dummy variable equaling one if the destination province is one of the Eastern provinces; ${ }^{8}$

PERIOD $_{\mathrm{t}}=$ dummy equaling one if the observation is from the $1995-2000$ period;

$\varepsilon_{\mathrm{ij}}=$ random error term

Railway distance and the migration rate are hypothesized to be inversely related; the greater is distance, the greater will be the direct costs of migration (train or bus fare, food and lodging expenses en route and upon arrival, for example) and the indirect costs of migration (for example, lost income due to down time between employment in the origin and employment in the destination, as well as the psychic costs of migration).

\footnotetext{
${ }^{6}$ The Northwestern provinces include Inner Mongolia, Xinjiang, Shaanxi, Gansu and Ningxia.

${ }^{7}$ The Southwestern provinces include Sichuan (including Chongqing), Guizhou, Yunnan, Qinghai and Guangxi.

${ }^{8}$ These include Beijing, Tianjin, Hebei, Liaoning, Shanghai, Jiangsu, Zhejiang, Fujian, Shandong, Guangdong and Hainan. Note that the Central provinces include Shanxi, Jilin, Heilongjiang, Anhui, Jiangxi, Henan, Hubei and Hunan.
} 
We hypothesize that the migration rate from province $i$ to province $j$ will be positively related to the size of the pre-existing migrant community in $\mathrm{j}$ that hails from $\mathrm{i}$ (the NETWORK variable). The greater is the size of the migrant community already in the destination, ceteris paribus the lower will be the costs of migrating because there will tend to be more information flowing back to the origin about employment and business opportunities, housing, schools, recreational opportunities, etc. Furthermore, there will be lower psychic costs of migration because a larger migrant community in the destination will tend to be a greater source of comfort, security and familiarity for those contemplating migration.

The migration rate is hypothesized to be positively related to lagged investments in the destination $\left(\mathrm{FDI}_{(\mathrm{j})(\mathrm{t}-\mathrm{k})}\right.$ and $\left.\mathrm{INV}_{(\mathrm{j})(\mathrm{t}-\mathrm{k})}\right)$ and negatively related to lagged investments in the origin $\left(\mathrm{FDI}_{(\mathrm{i})(\mathrm{t}-\mathrm{k})}\right.$ and $\left.\mathrm{INV}_{(\mathrm{i})(\mathrm{t}-\mathrm{k})}\right)$. Higher investment, e.g. new commercial or residential construction, in the destination will generate higher demand for labor from other provinces, higher wage rates and thus an increase in "demand-pull" migration. Conversely, higher investment in the origin will reduce the incentive to migrate from there, all other things equal, due to more attractive labor market opportunities at home.

The two investment variables are lagged for two important reasons. First, it will very likely take time for spending on new investment projects to result in in-migration of labor to the area. For example, spending on new construction of apartment buildings in Shanghai may not result in increased hiring there right away because it often takes time for information on local labor market conditions in the destination to flow to the origin province. Furthermore, migration is an activity that often cannot be undertaken right away, especially if it is relatively costly and migrants must save in advance in order to 
finance migration. Second, there is likely to be two-way causality between migration and contemporaneous investment. On the one hand, higher current investment in the destination may induce in-migration, but greater in-migration may itself encourage more investment. For example, when there is a large influx of migrants to Beijing in response to a construction boom, increased migrant demand for housing may stimulate construction spending there. ${ }^{9}$ If investment is endogenous to migration, then a simultaneous equations econometric model may be more appropriate. Consequently, to avoid the need for a simultaneous equations model, we use lagged investment because it will be exogenous to migration.

We include interactions between provincial FDI and fixed asset investment to account for the possibility that higher levels of one type of investment may influence the sensitivity of migration to a change in the other type. Suppose increased FDI results in greater commercial construction spending in the destination province, stimulating inmigration. Then the effect of the higher FDI on in-migration could be smaller the larger is the level of fixed asset investment spending, i.e. $\alpha_{8}$ could be negative. For example, construction firms financed by FDI may compete with firms financed internally for the same pool of imported labor. Consequently, increased demand for migrant labor by FDIfinanced firms may induce less supply of migrant labor to those firms when there is a higher level of fixed asset investment. By the same reasoning, the drop in out-migration due to higher FDI in the origin province could be smaller the higher is the level of fixed asset investment $\left(\alpha_{7}>0\right)$.

\footnotetext{
${ }^{9}$ FDI may also be functionally related to INV, and vice versa. If there is greater domestic fixed investment in a city, for example, this could induce more foreign investment (especially if local authorities offer to match foreign investment) or less foreign investment (if foreign investment is viewed as a substitute for domestic investment).
} 
The origin and destination provinces' shares of GDP attributable to manufacturing $\left(\mathrm{MANU}_{\mathrm{i}}\right.$ and $\mathrm{MANU}_{\mathrm{j}}$, respectively) are included as controls for industry mix in the province. The relationship between the dominance of manufacturing in the destination province and in-migration there is expected to be positive. Manufacturing jobs are generally higher-skilled and higher-paying compared to, for example, jobs in the agricultural sector. Therefore, provinces with relatively larger manufacturing sectors should attract relatively more migrants, all other things equal, especially from provinces that have relatively large agricultural sectors. Using the same reasoning, manufacturing's share of output in the origin province should be negatively related to out-migration from that province.

Following Bao, Hou and Shi (2006, pp. 335), we include a control for the relative proportion of the destination's population that is minority. ${ }^{10}$ We include this variable for several reasons and postulate that its effect on migration could be positive or negative. First, this variable may proxy general political conditions in the province, e.g. provinces with larger minority population shares may have more political divisiveness than other provinces, which may influence migration patterns. Second, there are several economic reasons why the minority population share may influence migration. As Bao, Hou and Shi (2006) point out, provinces with relatively large minority population shares tend to lack many basic service industries, hence entrepreneurial migrants seeking to start service businesses may find these provinces profitable places to relocate to. On the other hand, professionals seeking salaried positions may be less interested in migrating to provinces

\footnotetext{
${ }^{10}$ The proportion of a province's population that is minority was computed in the following way:

$\%$ of minority $=\left(\frac{\text { total population }- \text { Han population }}{\text { total population }}\right) \times 100$.
} 
with higher minority shares because they may perceive such provinces to have more limited high-skill employment opportunities.

The NORTHWEST, SOUTHWEST, EAST, and PERIOD controls are included to account for regional and period differences in migration. During the 1980s and part of the 1990s, Eastern China, particularly the coastal cities, experienced considerable prosperity relative to the West. This has been cited as a major factor for substantial Eastward migration during that period. Accordingly, the Western sub-regional dummies are included as controls for any ceteris paribus regional bias for or against migration to the Western part of China. The EAST dummy is included as a control for regional bias in migration for or against the Eastern part of the country. The PERIOD variable is included as a general control for increased deregulation of migration during the later period.

Following the earlier literature on internal migration, we hypothesize that migration rates will be positively related to real relative income in the destination $\left(\mathrm{Y}_{\mathrm{j}}\right)$, since the returns to migrating will be higher the greater is the real relative return to supplying one's labor services in the destination. Conversely, we hypothesize a negative relationship between the rate of migration and real income in the origin province $\left(\mathrm{Y}_{\mathrm{i}}\right)$. The migration rate is hypothesized to be positively related to the average level of educational attainment in the destination $\left(\mathrm{E}_{\mathrm{j}}\right)$ because the existence of a better educated labor force there usually means a distribution of higher quality employment opportunities. However, using the same type of argument, greater educational attainment in the origin (a higher value of $E_{i}$ ) is hypothesized to be inversely related to the migration rate. A higher relative unemployment rate in the destination $\left(\mathrm{U}_{\mathrm{j}}\right)$ is expected to discourage migration, but a higher unemployment rate in the origin $\left(\mathrm{U}_{\mathrm{i}}\right)$ is expected to encourage migration. Relative 
mean yearly temperature in the destination $\left(\mathrm{T}_{\mathrm{j}}\right)$ is included as a control for destination amenities. It is presumed that migrants prefer warmer provinces, all other things equal, hence migration rates to warmer provinces should be higher. However, ceteris paribus we hypothesize that migration rates out of warmer provinces will be smaller $\left(\alpha_{19}<0\right)$.

\section{DESCRIPTION OF DATA}

The data set used in this study is a modified version of a data set used by Lin, Wang and Zhao (2004). Lin, Wang and Zhao graciously shared their data set with us and we used most of it without any modifications. However, there are ten provincial data series included in our data set not found in Lin, Wang and Zhao's data set. First, we replaced their interprovincial migration rate series with our own. The reason is that there are some inaccuracies in the series used by Lin, Wang and Zhao, which they acknowledged in some very recent communications with us. Second, we added nine new variables -- the pre-existing migrant community in the destination, real FDI per capita in the origin and destination provinces, real domestic fixed asset investment per capita in the origin and destination provinces, the manufacturing sector's share of GDP in the destination and origin provinces and the minority population share in the origin and destination provinces.

Our data set consists of 1,577 observations at the province level spanning the period 1980-2000. There are 29 provinces in our data set ${ }^{11}$. Each of the 29 provinces was a prospective destination and a point of origin for migration flows. Because of the loglinear functional form for equation (1), the data set does not include any observations for

\footnotetext{
${ }^{11}$ As with Lin, Wang and Zhao (2004), we exclude Tibet because of missing observations and treat Chongqing as part of Sichuan.
} 
which the emigration rate is zero. Equation (1) was estimated for the full sample, for the 1980s separately and then for the 1990s separately. No data were available for size of the migrant network during the 1980s, so we estimated equation (1) without a migrant network variable for the 1980s sub-sample (765 observations), as well as for the full sample. However, data were available for the size of the migrant network during the 1990s, so we estimated equation (1) with and without a migrant network variable for the 1990s sub-sample. Again because of the log-linear functional form, we excluded observations for which the migrant network was zero, leaving us with 790 observations. ${ }^{12}$

Tables 1 and 2 show summary statistics for all variables used in our regressions for the1980s and 1990s sub-samples. Starting from the top of each table, we describe each variable, the data source from which the variable is drawn and the trends apparent in the data between the two periods:

(i) Gross interprovincial migration rate. This is the number of persons migrating from province $\mathrm{i}$ to province $\mathrm{j}$ divided by the number of persons migrating from province $\mathrm{i}$. These numbers are calculated from $1 \%$ of the 1990 population census and $0.95 \%$ of the 2000 population census ${ }^{13}$, both sets of numbers published by the China Statistical Press. In the 1990 (2000) census, respondents were asked to report on migration activities

\footnotetext{
${ }^{12}$ Note that while the full sample is 1,577 observations, the sum of the two subsamples is 1,555 observations. The reason is that in the full sample regression, since the migrant network variable was not included, it was not necessary to exclude 22 observations in the 1990s subsample for which the migrant network was zero.

${ }^{13}$ As pointed out by Lin, Wang and Zhao, there is a small difference between the 1990 and 2000 censuses with respect to how migration is defined. If a person is observed to change residence and to change their household registration (a situation called hukou migration), then this movement as classified as "migration" in both censuses. If, however, the person is observed to change residence without changing registration (the case of non-hukou migration), then the movement is classified as "migration" only if the migrant has been away from the place of registration for a minimum period of time. In the 2000 census, this period is 6 months, but in the 1990 census it is one year. To account for this change in classification between the two periods, the migration numbers in both periods were standardized by discounting the 2000 numbers by a small amount, approximately 5\%. For further details, see Lin, Wang and Zhao (2004, page 593).
} 
during 1985-90 (1995-2000). Consequently, migration rates during each decade were calculated for the second half of each decade only. The volume of migration at the provincial level more than doubled from over 365,000 persons during 1985-90 to nearly $1,500,000$ during $1995-2000 .{ }^{14}$ The surge in migration can generally be attributed to market reforms, deregulation of the hukou system and generally rising prosperity across the country. Note that between periods, mean provincial population rose $9.44 \%$. For both periods, Sichuan province experienced the highest volume of interprovincial emigration (approximately 1,457,000 persons during 1985-90 and 4,375,000 during 1995-2000), while Ningxia province had the lowest (approximately 54,500 persons during 1985-90 and 94,750 during $1995-2000)$. For the $1985-90$ period, the highest migration rate was $79.34 \%$ (Guangxi to Guangdong) and the lowest was $0.02 \%$ (a tie between Jingxi to Qinghai and Jingxi to Ningxia). During 1995-2000, the highest reported migration rate was $87.32 \%$ (also Guangxi to Guangdong) and the lowest was 0.14\% (Jingxi to Qinghai);

(ii) The size of the migrant network originally from province $i$ that resides in province $j$ (NETWORK). An ideal measure of the size of a migrant network is the relative stock of previous migrants residing in the destination province at the time the migration decision is made. Unfortunately, unlike data sets in the USA and many European countries, such a stock measure is not available in Chinese data sets. Therefore, we had to measure the size of the migrant community using data on past migrant flows. There are no data on interprovincial migrant flows prior to 1985 , so our regression analyses for the 1985-90 period could not include a control for migrant network effects. However, in our regression analyses for the $1995-2000$ period, 1985-1995 migrant flows could be used to

\footnotetext{
14 There are likely to be discrepancies in the calculations of these numbers between the two decades, for the reasons discussed in the preceding footnote.
} 
proxy the size of the migrant network during 1995-2000. Consequently, we estimated the size of the migrant community residing in province $j$ that hails from province $i$ in 2000 by taking the ratio of migration from $i$ to $j$ during $1985-95$ to $j$ 's population in 2000 . The assumption underlying these calculations is that the stock of previous migrants is proportional to the size of the previous flow of migrants. While not an ideal measure, we are confident that data on flows over a longer (10-year) period should be relatively accurate. Note from Table 2 that the average size of the migrant community in each province is approximately 25,000 persons;

(iii) Lagged real annual FDI per capita in the province. FDI data were obtained from the China Statistical Press. For each period, we used mean annual real FDI per capita, as well as mean annual real fixed asset investment per capita, during 1980-84 when regressing 1985-90 migration flows and 1990-94 when regressing 1995-2000 migration flows. In lagging investment spending this way, we are assuming that it takes on average up to 5 years for migration to respond to changes in spending on investment projects. We adjusted the investment series for cost of living differences between the two decades, as well as across provinces within each decade, using national government measures of provincial CPI and calculating both series at 1985 price levels. For most of the provinces, FDI numbers were available for each year, but for some there were missing years. For several provinces, no investment data were available for 1980-84, so we used the earliest year available as a proxy for that period. Therefore, our coefficient estimates for the early period may be influenced by measurement error in parts of the investment series. Note that the FDI series is in USA dollars, whereas the fixed asset investment series is in Yuan. 
Comparing Tables 1 and 2, there was a dramatic increase in FDI between the two periods, reflecting a surge in interest by international investors in the Chinese economy during the 1990s. In both periods, the places receiving the highest levels of FDI on a perperson basis tended to be the main cities in China. During 1980-84, Beijing received the most FDI (\$35.02 per capita), followed by Shanghai and Guangdong province. In contrast, Shandong received nearly zero FDI during 1980-84, followed by Gansu and Anhui provinces. During 1990-94, however, it was Shanghai that was the largest recipient of FDI ( $\$ 50.53$ per capita), whereas Qinghai province had the lowest $(\$ 0.38$ per capita).

(iv) Domestic real annual fixed investment per capita. These numbers were calculated using the same methods as for real FDI per capita and with numbers obtained from China Statistical Press. China experienced a dramatic increase in fixed asset investment between the two decades, reflecting a boom in residential and commercial construction. However, there is great disparity across provinces with respect to the level of construction spending. During 1980-84, Shanghai experienced the highest level of fixed investment (686.75 Yuan per capita), whereas Guangxi province experienced the lowest (57.65 Yuan per capita). During 1990-1994 Beijing experienced the highest level (approximately 1,900 Yuan per capita), whereas Guizhou experienced the lowest (approximately 160 Yuan per capita);

(v) The manufacturing sector's share of provincial output. These data were obtained from the China Statistical Yearbooks. Technically, manufacturing is classified as the "Secondary" industry in China and it includes construction as one of the components. There is considerable variation in the dominance of the manufacturing sector across 
China. During 1980-85, Shanghai had the highest manufacturing share (approximately two-thirds of its GDP), whereas the lowest share was in Hainan (20.56\%). During 19952000, Heilongjiang province had the highest manufacturing share (approximately 55\%), whereas the lowest was in Hainan province (just under 21\%).

(vi) The share of the province's population that is minority. These are 2000 census data obtained from the China Statistical Yearbooks. Because data for 1990 are not available, we used the 2000 data to proxy minority population shares during the 1980s, as well as during the 1990s. One can see that the minority population share varied widely across provinces in 2000.

Data on the remaining variables are from Lin, Wang and Zhao; please refer to their paper for details on data sources and measurement of these variables:

(vi) Mean real per capita income. Note that income data for the earlier period are for 1989 (deflated to 1985 levels), whereas for the later period are for 1999 (deflated to 1995 levels). For both periods, the highest income area was Shanghai and the lowest was Gansu province;

(vii) Mean years of schooling. During both periods, the most well-educated population was Beijing, whereas the lowest was Guizhou province. Note that educational attainment rose by nearly $25 \%$ between periods, despite secondary education not being free in China; (viii) Unemployment rates. There are considerable differences between periods in the behavior of the unemployment rate. The unemployment rate increased dramatically in the later period. The highest unemployment rates occurred in the metropolitan areas (Beijing 
during 1985-90 and Shanghai during 1995-2000), whereas the lowest unemployment rates were in Shandong (1985-90) and Yunnan (1995-2000).

\section{EMPIRICAL RESULTS}

Table 3 shows OLS coefficient estimates for four different versions of equation (1). We first estimated the equation for the full sample (migrant flows for 1985-90 and 19952000 combined). We then estimated equation (1) separately for each period. Note that the full sample and 1980s-only regressions do not include the migrant network variable (NETWORK) due to absence of data on pre-1985 migration patterns. Also, for the 1990sonly regression, we estimated two equations - one with the migrant network variable and one without.

Starting from the top row of the table, we find very strong evidence of a "migrant network" effect; the coefficient on past migrant flows is positive and significant at better than $1 \%$ and predicts that a $1 \%$ increase in the size of the destination province's preexisting community of migrants hailing from the origin province will, all other things equal, result in the rate of migration being higher by approximately $0.5 \%$. This supports the general hypothesis that larger migrant networks encourage migration because they lead to lower informational and psychic costs of migration.

It is important to interpret the estimated coefficient on the migrant network measure in conjunction with the estimated coefficient on railway distance, as well as in the context of the results on railway distance obtained in Lin, Wang and Zhao's (2004, page 597) study. First, note that the distance coefficient is negative and significant at better than $1 \%$ for all four regressions. For example, in the regression conducted on the full sample, when distance is $1 \%$ greater the interprovincial migration rate falls by over $1.2 \%$. This is 
consistent with theory; greater distance raises the costs of migration, direct and indirect, and deters migration. Second, observe that the distance coefficient is much less negative in the later period regression when the migrant network variable is included. In fact, our coefficients for distance in the full sample and early period regressions are similar to the coefficients obtained by Lin, Wang and Zhao (who did not control for migrant networks). Lin, Wang and Zhao obtained a coefficient of $-1.27 \%$ for the early period and $-0.9 \%$ for the later period. Both studies demonstrate that migration is generally less sensitive to distance in the later period, but our study further demonstrates that the sensitivity is much lower when a control for past migration is included.

We contend that distance and the size of the migrant network are linked by the costs of migration; greater distance tends to increase costs, whereas a larger migrant community in the destination tends to reduce them. We concur with Lin, Wang and Zhao (pp. 596) that the reason their distance coefficient was less negative in the later period is because, and we quote them, "....it is also possible that the psychic costs of migration are declining due to the expansion of migrant networks in destinations so that long-distance migration is less intimidating." Lin, Wang and Zhao's results for the distance variable between periods likely reflect the growth in the size of the migrant network in the later period, but also omitted variables bias. The distance variable in their regressions is likely capturing the effects on the migration rate of an omitted migrant networks variable.

Furthermore, the reason our distance coefficient in the later period regression was much more negative when a migrant network control was excluded is because that coefficient reflects omitted variables bias. All this underscores the importance of including a control for past migration when studying the determinants of internal migration. 
Some of the estimated coefficients on the income variables are supportive of theory and confirm that, all other things equal, a widening of the real destination/origin income differential stimulates migration. For the later period regression which includes the migrant network variable, for example, the estimated coefficient on origin income is negative and significant at better than $1 \%$, predicting that a $1 \%$ increase in income at home will lower the out-migration rate by $1.67 \%$. This is supportive of theory. In contrast, for the early period regression we predict that a $1 \%$ increase in origin income will, all other things equal, induce a $1.06 \%$ increase in the out-migration rate. That result is not supportive of theory. The coefficients on destination income across all four regressions are all consistent with theory and are significant at better than $1 \%$. For the full sample, the coefficient predicts that a $1 \%$ increase in real per capita income in the destination will raise the in-migration rate by $1.76 \%$. Note, however, that in-migration appears to be more sensitive to a change in destination income in the earlier period. This is opposite to the results of Lin, Wang and Zhao (pp. 597), who found that in-migration was more sensitive to real income differences in the later period.

According to Table 3, out-migration rates are ceteris paribus lower in provinces where on average the population is better educated. This may reflect a greater supply of higherpaying, higher-skilled jobs, which may reduce the incentive to migrate. In contrast, the regressions strongly indicate that in-migration rates will ceteris paribus be higher in those provinces that are on average better educated, suggesting that people are attracted to provinces with a greater supply of high-skilled jobs. Note the relatively large coefficients on the schooling variables. For example, for the full sample when mean educational attainment in the origin is $1 \%$ higher, the out-migration rate is $1.65 \%$ lower, all other 
things equal; when mean education attainment in the destination is $1 \%$ higher, the inmigration rate is $1.37 \%$ higher. The large coefficients indicate the social externalities that come with higher education, e.g. better quality jobs, higher returns to all economic activities in the province and a higher quality of life. Note also that the responsiveness of migration to a province's educational endowment is considerably stronger during the later period, providing some confirmation to the findings of Lin, Wang and Zhao (2004) that as China's economic reforms deepened during the 1990s, migration became more responsive to changes in labor market conditions.

Estimates for the coefficient on the origin province's unemployment rate are generally not supportive of theory. In fact, for the full sample, higher unemployment rates at home appear to deter out-migration, all other things equal. One possible explanation is that weakening labor markets at home may make out-migration less affordable, particularly for lower-income prospective migrants. However, the estimated coefficients on the destination province's unemployment rate are all consistent with theory. For example, for the full sample regression, when the destination's unemployment rate rises by $1 \%$, the inmigration rate falls by $0.48 \%$, all other things equal. Note, however, that the responsiveness of migration to the destination unemployment rate is milder during the later period. This indicates that migration was actually not more responsive to changing labor market conditions during a period in which barriers to migration were lower.

Provincial differences in the dominance of manufacturing appear on balance to help explain differences in interprovincial migration rates. However, some signs switch between periods, indicating an ambiguous relationship between provincial industry mix and migration rates. During the early period, for example, a $1 \%$ increase in 
manufacturing's share of GDP in the origin province leads to $0.83 \%$ drop in the outmigration rate, but during the later period (when the migrant network variable is excluded) the out-migration rate rises by $0.68 \%$. The same sort of pattern occurs for the estimated coefficients on the destination province's share of manufacturing. For the early period, a $1 \%$ increase in the manufacturing share lowers the rate of in-migration by $2.3 \%$, but in the later period the in-migration rate increased by approximately $1.5 \%$. This reversal of signs is a subject for future research, especially since very little is known about how internal migration in developing countries responds to changes in industry mix.

We find that migration rates are influenced by the level of ethnic diversity in the province during the 1980s, but not during the 1990s. During the early period, a $1 \%$ increase in the origin province's minority share induces a $0.07 \%$ increase in the outmigration rate; a $1 \%$ increase in the destination province's minority share induces a $0.09 \%$ drop in the in-migration rate. These results indicate that increasing ethnic diversity in a province discourages migration to that province and encouraged migration from the province. This result is opposite to the one obtained by Bao, Hou and Shi (2006, pp. 336), who found that Western provinces with higher minority population shares appear to be more attractive to immigration from other provinces. Bao, Hou and Shi note that Western provinces with larger minority population shares tend to be more agricultural, have weaker commercial and service economies, tend to have more tourist attractions and receive larger subsidies for minority groups. These factors combined may have resulted in greater migration to those particular provinces, especially since Westward migrants 
may be attracted to entrepreneurial opportunities in the commercial and service sectors. We find that not to be the case at the national level, however.

Provinces with warmer temperatures appear to offer migrants a preferred amenity; in the full sample regression, when a province is warmer by $1 \%$ Celsius, all other things equal, the out-migration rate falls by about $0.6 \%$. However, in the full sample regression destination temperature appears to have no effect on in-migration. Warmer provinces have lower out-migration rates during the early period, but not during the later period. In contrast, during the later period warmer provinces had higher in-migration rates. Some of these results appear to support the hypothesis that migrants respond not only to spatial differences in real incomes, but also to spatial differences in amenities such as climate.

We obtain very mixed results for the estimated effects of fixed asset investment on migration patterns. For the early period, there is as hypothesized an inverse relationship between investment in the origin and out-migration, but the relationship is not statistically significant. For the full sample and later period regressions, however, the relationship is positive and significant, which disconfirms our hypothesis. In contrast, for the later period a $1 \%$ increase in investment in the destination is estimated to increase inmigration by just under $0.3 \%$, confirming our hypothesis, but for the other regressions the relationship between destination investment and in-migration is apparently negative. One possible explanation for the positive relationship between origin investment and outmigration is that more investment spending, by creating greater overall prosperity, could help make out-migration more affordable than before.

While the coefficient estimates for real FDI in the origin province do not confirm our hypothesis, the estimates for FDI in the destination are consistently supportive and 
robust. For example, for the full sample regression, a $1 \%$ increase in destination FDI induces a $0.25 \%$ increase in the in-migration rate, all other things equal. Note that the responsiveness of in-migration to FDI is considerably greater during the 1990s, which may reflect the effects of lower barriers to migration during that period. For example, during the later period we estimate that when real FDI rises by $1 \%$, in-migration rises by over $1.25 \%$.

We find strong evidence that the marginal effect of provincial fixed asset investment (FDI) on migration rates is negatively influenced by the level of FDI (provincial fixed asset investment). For example, for the full sample, when one type of investment in the destination province rises by $1 \%$, the marginal effect on migration of the other type of investment will fall by approximately $0.03 \%$. We obtain the same sort of result, although stronger, for the later period. Furthermore, we find some evidence of a negative interaction effect between both types of investment for the origin. We take these results to suggest that foreign-financed and internally-financed investment projects in a province may compete for imported labor, hence when imported labor supply to one type of investment project rises, imported supply to the other will be less responsive.

For the full sample and early period regressions, ceteris paribus, migration rates to the two Western sub-regions were higher than they were to the Central provinces, with migration rates to the Southwest provinces being even higher. These results, taken together, indicate that ceteris paribus Westward migration was higher over both periods, but not during the 1990s. Migration rates to the Eastern provinces were also generally higher than to the Central provinces, but only during the early period. However, all other 
things equal, interprovincial migration rates nationwide were actually about $0.6 \%$ lower during the 1990s.

\section{CONCLUDING REMARKS}

We have established in this study that, in addition to spatial differences in labor market conditions, climate, and human capital endowments, there are other important determinants of province-to-province migration flows in China. The most important of these are migrant networks; migration during 1995-2000 appears to have been strongly influenced by migration flows during the previous ten years. We found that when we controlled for network effects in our regressions, the marginal effect of distance on migration flows fell appreciably, thus the very strong effects of distance on migration found in Lin, Wang and Zhao (2004) were likely to be upwardly biased due to the omission of a migrant network control. Thus, in any study of internal migration in China, it is crucial to control for past migration.

We find strong evidence that destination FDI encourages in-migration and some evidence that destination fixed asset investment encourages in-migration. Higher levels of fixed asset investment in the origin were found to be associated with higher levels of out-migration, a result that requires further investigation. Our mixed results for the investment variables suggest that further investigation of the relationship between provincial investment spending and migration is needed. The majority of our results for the variables used in previous studies of interprovincial migrant flows generally replicate the findings of previous researchers. However, our evidence does not seem to offer much 
support for earlier findings that as China's economic reforms deepened during the 1990s, the structure of migration changed.

For internal migration researchers, China is and will continue to be a significant natural experiment in deregulation of migration, coinciding with national economic prosperity, market-oriented reforms, foreign direct investment and globalization. There is great need for future research on this subject, as interregional labor mobility will be a prime contributor to China's success in completing its transition to a market economy.

\section{REFERENCES}

Bao, Shuming, Jack W. Hou and Anqing Shi (2006), "Migration and Regional Development in China," in Shuming Bao, Shuanglin Lin and Changwen Zhao (editors), Chinese Economy after WTO Accession, Aldershot, UK: Ashgate.

Greenwood, Michael J. (1997), "Internal Migration in Developed Economies," in Handbook of Population and Family Economics (Mark R. Rosenzweig and Oded Stark, editors), Amsterdam: Elsevier B.V., pp. 647-720.

Liang, Zai (2001), "The Age of Migration in China," Population and Development Review, 27, September, pp. 499-524.

Liang, Zai, Yiu Por Chen and Yanmin Gu (2002), "Rural Industrialisation and Internal Migration in China," Urban Studies, 39, 12, pp. 2175-87.

Liang, Zai and Michael J. White (1996), "Internal Migration in China, 1950-88," Demography, 33, August, pp. 375-84.

(1997), "Market Transition, Government Policies, and Interprovincial Migration in China: 1983-1988," Economic Development and Cultural Change, 45, 2, pp. 321-39.

Lin, Justin, Gewei Wang and Yaohui Zhao (2004), "Regional Inequality and Labor Transfers in China," Economic Development and Cultural Change, 52, April, pp. 587603.

Poncet, Sandra (2006), "Provincial Migration Dynamics in China: Borders, Costs and Economic Motivations," Regional Science and Urban Economics, 36, pp. 385-98. 
Zhao, Yaohui (2002), "Causes and Consequences of Return Migration: Recent Evidence from China," Journal of Comparative Economics, $\underline{30}$, pp. 376-94.

(1999a), "Labor Migration and Earnings Differences: The Case of Rural China," Economic Development and Cultural Change, 47, 4, pp. 767-82.

(1997), "Labor Migration and Returns to Rural Education in China," American Journal of Agricultural Economics, 79, November, pp. 1278-87.

(1999b), "Leaving the Countryside: Rural-to-Urban Migration Decisions in China," American Economic Review, 9, 2, pp. 281-86.

(2003), "The Role of Migrant Networks in Labor Migration: The Case of China," Contemporary Economic Policy, 21, October, pp. 500-11. 


\section{TABLE 1 \\ Summary Statistics for Provinces in 1980s sub-sample (765 observations)}

\begin{tabular}{|c|c|c|c|c|}
\hline Variable & Mean & $\begin{array}{l}\text { Standard } \\
\text { Deviation }\end{array}$ & Maximum & Minimum \\
\hline $\begin{array}{l}\text { Province-to- } \\
\text { province emigration } \\
\text { rate (out of total } \\
\text { emigration from the } \\
\text { origin province) }\end{array}$ & $3.7747 \%$ & $6.9823 \%$ & $79.336 \%$ & $0.018047 \%$ \\
\hline $\begin{array}{l}\text { Real Mean Annual } \\
\text { FDI Per Capita } \\
\text { (Between } 1980 \text { and } \\
\text { 1984) }\end{array}$ & \$US 1.77 & \$US 6.57 & \$US 35.02 & \$US 0.01 \\
\hline $\begin{array}{l}\text { Real Mean Annual } \\
\text { Fixed Asset } \\
\text { Investment Per } \\
\text { Capita (Between } \\
1980 \text { and 1984) }\end{array}$ & 205.65 Yuan & 167.58 Yuan & 686.75 Yuan & 57.65 Yuan \\
\hline $\begin{array}{l}\text { Railway distance } \\
\text { between capital } \\
\text { cities of origin and } \\
\text { destination } \\
\text { provinces }\end{array}$ & $\begin{array}{l}1,630.76 \\
\text { Kilometers }\end{array}$ & 1.87 Kilometers & $\begin{array}{l}6,313.21 \\
\text { Kilometers }\end{array}$ & $\begin{array}{l}137 \\
\text { Kilometers }\end{array}$ \\
\hline $\begin{array}{l}\text { Mean per capita } \\
\text { income }\end{array}$ & 507.82 Yuan & 184.91 Yuan & $\begin{array}{l}1,084.53 \\
\text { Yuan }\end{array}$ & 340.53 Yuan \\
\hline $\begin{array}{l}\text { Mean years of } \\
\text { schooling }\end{array}$ & 6.426 & 1.248 & 9.463 & 4.379 \\
\hline Unemployment rate & $1.214 \%$ & $0.767 \%$ & $4.11 \%$ & $0.28 \%$ \\
\hline $\begin{array}{l}\text { Manufacturing } \\
\text { share of GDP }\end{array}$ & $42.63 \%$ & $9.81 \%$ & $66.79 \%$ & $20.56 \%$ \\
\hline $\begin{array}{l}\text { Mean yearly } \\
\text { temperature }\end{array}$ & $14.113 \mathrm{C}$ & $5.176 \mathrm{C}$ & $24.517 \mathrm{C}$ & $4.608 \mathrm{C}$ \\
\hline $\begin{array}{l}\text { Minority population } \\
\text { share }\end{array}$ & $12.28 \%$ & $16.06 \%$ & $59.43 \%$ & $0.31 \%$ \\
\hline
\end{tabular}


TABLE 2

Summary Statistics for Provinces in 1990s sub-sample

\begin{tabular}{|l|l|l|l|l|}
\hline Variable & Mean & $\begin{array}{l}\text { Standard } \\
\text { Deviation }\end{array}$ & Maximum & Minimum \\
\hline $\begin{array}{l}\text { Province-to- } \\
\text { province } \\
\text { emigration rate } \\
\text { (out of total } \\
\text { emigration from } \\
\text { the origin } \\
\text { province) }\end{array}$ & $3.5886 \%$ & $7.2295 \%$ & $87.317 \%$ & $0.01436 \%$ \\
\hline $\begin{array}{l}\text { Number of persons } \\
\text { in the } \\
\text { destination's pre- } \\
\text { existing migrant } \\
\text { community }\end{array}$ & 24,985 & 68,541 & 893,200 & 100 \\
\hline $\begin{array}{l}\text { Real Mean Annual } \\
\text { FDI Per Capita } \\
\text { (Between 1980 } \\
\text { and 1984) }\end{array}$ & $\$ \mathrm{US} 9.95$ & $\$ \mathrm{US} \mathrm{14.07}$ & $\$ \mathrm{US} \mathrm{50.53}$ & $\$ \mathrm{US} 0.38$ \\
\hline $\begin{array}{l}\text { Real Mean Annual } \\
\text { Fixed Asset } \\
\text { Investment Per } \\
\text { Capita (Between } \\
\text { 1980 and 1984) }\end{array}$ & 563.55 Yuan & 424.91 Yuan & 1890.3 Yuan & 160.31 Yuan \\
\hline $\begin{array}{l}\text { Railway distance } \\
\text { between capital } \\
\text { cities of origin } \\
\text { and destination } \\
\text { provinces }\end{array}$ & $1,630.76$ Kilometers & 1.87 Kilometers & $6,313.21$ & 137 Kilometers \\
\hline $\begin{array}{l}\text { Manufacturing } \\
\text { share of GDP }\end{array}$ & $44.52 \%$ & Kilometers & \\
\hline $\begin{array}{l}\text { Mean per capita } \\
\text { income }\end{array}$ & $1,062.61$ Yuan & 447.27 Yuan & $2,451.51$ Yuan & 605.26 Yuan \\
\hline $\begin{array}{l}\text { Mean years of } \\
\text { schooling }\end{array}$ & 7.976 & 1.038 & 10.558 & 5.974 \\
\hline $\begin{array}{l}\text { Unemployment } \\
\text { rate }\end{array}$ & $4.392 \%$ & $2.445 \%$ & $9.64 \%$ & $1.36 \%$ \\
\hline $\begin{array}{l}\text { Mean yearly } \\
\text { temperature }\end{array}$ & $14.113 \mathrm{C}$ & $5.176 \mathrm{C}$ & $24.517 \mathrm{C}$ & $4.608 \mathrm{C}$ \\
\hline $\begin{array}{l}\text { Minority } \\
\text { population share }\end{array}$ & $12.28 \%$ & $16.06 \%$ & $59.43 \%$ & $0.31 \%$ \\
\hline
\end{tabular}


TABLE 3

OLS REGRESSION RESULTS

Dependent Variable $=$ Gross Interprovincial Migration Rate

(Standard Errors in Parentheses; ** denotes significant at 1\%, * at 5\%,)

\begin{tabular}{|c|c|c|c|c|}
\hline REGRESSOR & $\begin{array}{l}\text { FULL } \\
\text { SAMPLE }\end{array}$ & $\begin{array}{l}\text { EARLY } \\
\text { PERIOD ONLY }\end{array}$ & $\begin{array}{l}\text { LATER } \\
\text { PERIOD ONLY }\end{array}$ & $\begin{array}{l}\text { LATER } \\
\text { PERIOD } \\
\text { ONLY }\end{array}$ \\
\hline Migrant Network & & & $\begin{array}{l}0.4910^{* * *} \\
(0.0217)\end{array}$ & \\
\hline Distance & $\begin{array}{l}-1.2105^{* *} \\
(0.0493)\end{array}$ & $\begin{array}{l}-1.3699 * * \\
(0.0702)\end{array}$ & $\begin{array}{l}-0.4260 * * \\
(0.0556)\end{array}$ & $\begin{array}{l}-1.0926^{* *} \\
(0.0610)\end{array}$ \\
\hline $\begin{array}{l}\text { Real income in } \\
\text { origin }\end{array}$ & $\begin{array}{l}0.3068 \\
(0.2002)\end{array}$ & $\begin{array}{l}1.0637^{* * *} \\
(0.2819)\end{array}$ & $\begin{array}{l}-1.6691^{* *} \\
(0.2264)\end{array}$ & $\begin{array}{l}-1.0326^{* * *} \\
(0.29)\end{array}$ \\
\hline $\begin{array}{l}\text { Real income in } \\
\text { destination }\end{array}$ & $\begin{array}{l}1.7622 * * \\
(0.2167)\end{array}$ & $\begin{array}{l}1.9247^{* *} \\
(0.3098)\end{array}$ & $\begin{array}{l}0.8110^{* * *} \\
(0.2197)\end{array}$ & $\begin{array}{l}1.0792 * * \\
(0.2835)\end{array}$ \\
\hline $\begin{array}{l}\text { Education level in } \\
\text { origin }\end{array}$ & $\begin{array}{l}1.6544 * * \\
(0.2714)\end{array}$ & $\begin{array}{l}-1.4879 * * \\
(0.3271)\end{array}$ & $\begin{array}{l}2.6371 * * \\
(0.3862)\end{array}$ & $\begin{array}{l}-2.589^{* * *} \\
(0.499)\end{array}$ \\
\hline $\begin{array}{l}\text { Education level in } \\
\text { destination }\end{array}$ & $\begin{array}{l}1.3741 * * \\
(0.2995)\end{array}$ & $\begin{array}{l}1.4893^{* * *} \\
(0.3634)\end{array}$ & $\begin{array}{l}2.2344 * * \\
(0.3987)\end{array}$ & $\begin{array}{l}2.1925^{* *} \\
(0.5151)\end{array}$ \\
\hline $\begin{array}{l}\text { Unemployment } \\
\text { rate in origin }\end{array}$ & $\begin{array}{l}-0.2720^{* *} \\
(0.0812)\end{array}$ & $\begin{array}{l}-0.1957^{*} \\
(0.1143)\end{array}$ & $\begin{array}{l}0.1166 \\
(0.1002)\end{array}$ & $\begin{array}{l}-0.0471 \\
(0.1292)\end{array}$ \\
\hline $\begin{array}{l}\text { Unemployment } \\
\text { rate in destination }\end{array}$ & $\begin{array}{l}-0.4750^{* * *} \\
(0.0883)\end{array}$ & $\begin{array}{l}-0.8347 * * \\
(0.1201) \\
\end{array}$ & $\begin{array}{l}-0.4479 * * \\
(0.1123)\end{array}$ & $\begin{array}{l}-0.4871^{* *} \\
(0.1450)\end{array}$ \\
\hline $\begin{array}{l}\text { Manufacturing } \\
\text { share of GDP in } \\
\text { origin }\end{array}$ & $\begin{array}{l}-0.4507 \\
(0.2317)\end{array}$ & $\begin{array}{l}-0.9580 * * \\
(0.3324)\end{array}$ & $\begin{array}{l}-0.4494 \\
(0.2473)\end{array}$ & $\begin{array}{l}0.6828^{* *} \\
(0.3192)\end{array}$ \\
\hline $\begin{array}{l}\text { Manufacturing } \\
\text { share of GDP in } \\
\text { destination }\end{array}$ & $\begin{array}{l}-0.7845^{* *} \\
(0.2340)\end{array}$ & $\begin{array}{l}-2.3037 * * \\
(0.3380)\end{array}$ & $\begin{array}{l}1.4966 * * \\
(0.2433)\end{array}$ & $\begin{array}{l}1.0641 \\
(0.3133)\end{array}$ \\
\hline $\begin{array}{l}\text { Minority share in } \\
\text { origin }\end{array}$ & $\begin{array}{l}0.0255 \\
(0.0220)\end{array}$ & $\begin{array}{l}0.0659^{* *} \\
(0.0318)\end{array}$ & $\begin{array}{l}0.0164 \\
(0.0226)\end{array}$ & $\begin{array}{l}0.0182 \\
(0.0292)\end{array}$ \\
\hline $\begin{array}{l}\text { Minority share in } \\
\text { destination }\end{array}$ & $\begin{array}{l}-0.0512 \\
(0.0269)\end{array}$ & $\begin{array}{l}-0.0926^{* *} \\
(0.0395)\end{array}$ & $\begin{array}{l}0.0341 \\
(0.0265)\end{array}$ & $\begin{array}{l}0.0473 \\
(0.0342)\end{array}$ \\
\hline $\begin{array}{l}\text { Temperature in } \\
\text { origin }\end{array}$ & $\begin{array}{l}-0.6114 * * \\
(0.1159)\end{array}$ & $\begin{array}{l}-0.4869^{* *} \\
(0.1695)\end{array}$ & $\begin{array}{l}-0.2151 \\
(0.1325)\end{array}$ & $\begin{array}{l}-0.2239 \\
(0.1712)\end{array}$ \\
\hline $\begin{array}{l}\text { Temperature in } \\
\text { destination }\end{array}$ & $\begin{array}{l}-0.0377 \\
(0.1193)\end{array}$ & $\begin{array}{l}-0.7834 * * \\
(0.1867)\end{array}$ & $\begin{array}{l}0.6940 * * \\
(0.1354)\end{array}$ & $\begin{array}{l}0.6915^{* *} \\
(0.1750)\end{array}$ \\
\hline $\begin{array}{l}\text { Real fixed asset } \\
\text { investment in } \\
\text { origin }\end{array}$ & $\begin{array}{l}0.3415^{* *} \\
(0.0843)\end{array}$ & $\begin{array}{l}-0.0984 \\
(0.1183)\end{array}$ & $\begin{array}{l}1.8806^{* * *} \\
(0.1389)\end{array}$ & $\begin{array}{l}1.4036^{* * *} \\
(0.1774)\end{array}$ \\
\hline $\begin{array}{l}\text { Real fixed asset } \\
\text { investment in } \\
\text { destination }\end{array}$ & $\begin{array}{l}-0.4541^{* *} \\
(0.0908)\end{array}$ & $\begin{array}{l}-0.5008^{* *} \\
(0.1192)\end{array}$ & $\begin{array}{l}-0.3586^{* *} \\
(0.1537)\end{array}$ & $\begin{array}{l}0.2938^{*} \\
(0.1950)\end{array}$ \\
\hline Real FDI in origin & $\begin{array}{l}0.1436 \\
(0.0966)\end{array}$ & $\begin{array}{l}0.5186^{* *} \\
(0.1801)\end{array}$ & $\begin{array}{l}0.2115 \\
(0.2198)\end{array}$ & $\begin{array}{l}0.9778^{* *} \\
(0.2806)\end{array}$ \\
\hline
\end{tabular}




\begin{tabular}{|c|c|c|c|c|}
\hline $\begin{array}{l}\text { Real FDI in } \\
\text { destination } \\
\text { province }\end{array}$ & $\begin{array}{l}0.2457 * * \\
(0.0953)\end{array}$ & $\begin{array}{l}0.4905 * * \\
(0.1847)\end{array}$ & $\begin{array}{l}1.2570 * * \\
(0.2203)\end{array}$ & $\begin{array}{l}1.1394 * * \\
(0.2846)\end{array}$ \\
\hline $\begin{array}{l}\text { Real FDI x Real } \\
\text { fixed asset } \\
\text { investment } \\
\text { interaction for } \\
\text { origin province }\end{array}$ & $\begin{array}{l}-0.0041 \\
(0.0167)\end{array}$ & $\begin{array}{l}-0.0754 * * \\
(0.0332)\end{array}$ & $\begin{array}{l}-0.0273 \\
(0.0363)\end{array}$ & $\begin{array}{l}-0.1421 * * \\
(0.0465)\end{array}$ \\
\hline $\begin{array}{l}\text { Real FDI x fixed } \\
\text { asset investment } \\
\text { interaction for } \\
\text { destination } \\
\text { province }\end{array}$ & $\begin{array}{l}-0.0269 * \\
(0.0163)\end{array}$ & $\begin{array}{l}-0.0585 \\
(0.0340)\end{array}$ & $\begin{array}{l}-0.1846^{* *} \\
(0.0359)\end{array}$ & $\begin{array}{l}-0.1804 * * \\
(0.0464)\end{array}$ \\
\hline $\begin{array}{l}\text { Control for } \\
\text { migration flows to } \\
\text { Northwest } \\
\text { provinces }\end{array}$ & $\begin{array}{l}0.5434 * * \\
(0.0995)\end{array}$ & $\begin{array}{l}0.7911 * * \\
(0.1374)\end{array}$ & $\begin{array}{l}-0.0125 \\
(0.1075)\end{array}$ & $\begin{array}{l}0.3191 * * \\
(0.1376)\end{array}$ \\
\hline $\begin{array}{l}\text { Control for } \\
\text { migration flows to } \\
\text { Southwest } \\
\text { provinces }\end{array}$ & $\begin{array}{l}0.3839 * * \\
(0.1215)\end{array}$ & $\begin{array}{l}0.7204 * * \\
(0.1665)\end{array}$ & $\begin{array}{l}-0.0607 \\
(0.1291)\end{array}$ & $\begin{array}{l}0.2217 \\
(0.1660)\end{array}$ \\
\hline $\begin{array}{l}\text { Control for } \\
\text { migration flows to } \\
\text { Eastern provinces }\end{array}$ & $\begin{array}{l}0.4310 * * \\
(0.1138)\end{array}$ & $\begin{array}{l}0.6011 * * \\
(0.1539)\end{array}$ & $\begin{array}{l}0.0340 \\
(0.1344)\end{array}$ & $\begin{array}{l}0.2047 \\
(0.1734)\end{array}$ \\
\hline Period control & $\begin{array}{l}-0.9305 * * \\
(0.1553)\end{array}$ & & & \\
\hline Constant & $\begin{array}{l}-1.7337 \\
(1.726)\end{array}$ & $\begin{array}{l}-4.4096 \\
(2.306)\end{array}$ & $\begin{array}{l}6.007 * * \\
(2.400)\end{array}$ & $\begin{array}{l}-0.7815 \\
(3.076)\end{array}$ \\
\hline $\begin{array}{l}\text { Adjusted R- } \\
\text { squared }\end{array}$ & 0.4887 & 0.5256 & 0.7324 & 0.5533 \\
\hline SSE & 1758.5 & 779.15 & 404.92 & 676.77 \\
\hline Sample size & 1,577 & 765 & 790 & 790 \\
\hline
\end{tabular}

